\title{
Pemodelan Gerak 2 Dimensi Berbasis GUI Matlab dengan Ketinggian Awal Tertentu
}

\section{Rustan}

Program Studi Fisika, Fakultas Sains dan Teknologi, Universitas Jambi

Jl. Jambi-Ma.Bulian km.15, Mendalo Indah, Muaro Jambi, 363631, Jambi, Indonesia

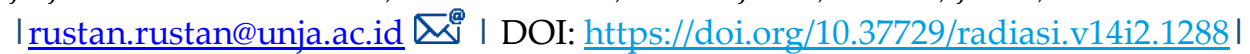

\begin{abstract}
Abstrak
Dalam ilmu fisika terdapat banyak persamaan matematis dan konsep abstrak yang sulit dipersepsikan secara indra oleh peserta didik. Hal tersebut dapat diatasi dengan memberikan visualisasi baik dalam bentuk visualisasi diam seperti gambar, grafik, dan foto maupun dalam bentuk visualisasi bergerak seperti video, pemodelan, dan animasi. Pada penelitian ini, akan dilakukan pemodelan gerak parabola dengan ketinggian awal tertentu menggunakan GUI Matlab untuk melihat respon waktu tempuh, jarak tempuh, dan kecepatan benda. Selain itu akan dilakukan variasi nilai parameter sudut pelemparan dan kecepatan awal. Hasil menunjukkan pemodelan gerak parabola menggunakan GUI Matlab memiliki tampilan menarik dan fitur yang dapat diubah sesuai keinginan pengguna (user). Objek yang dilempar pada ketinggian awal tertentu akan menempuh jarak terjauhnya saat sudut pelemparan awal sebesar $30^{\circ}$, dan akan menempuh jarak terpendeknya saat sudut pelemparan sebesar $60^{\circ}$. Pengembangan kode matlab pada pemodelan ini bertujuan untuk memberikan gambaran kualitatif sebagai pendukung pemahaman secara kuantitatif gerak parabola, dimana selama ini buku teks hanya menekankan pada aspek kuantitatifnya.
\end{abstract}

Article Info:

Recieved:

$14 / 07 / 2021$

Revised:

07/09/2021

Accepted:

$13 / 09 / 2021$

Keyword: Gerak parabola, Pemodelan, GUI Matlab

\begin{abstract}
Physics science has many mathematical equations and abstract concepts that are difficult for students to visualize. This can be overcome by providing visualizations both in the form of static visualizations such as images, graphics, and photos as well as in the form of dinamic visualizations such as videos, modeling, simulations, and animations. In this study, a parabolic motion modeling with a certain initial height will be carried out using GUI Matlab to see the response of time, distance, and velocity. In addition, variations of angle and initial velocity will be carried out. In this model, it is assumed that air friction is negligible. The results show that the parabolic motion modeling using GUI Matlab has an better display and features that can be modified by user. An object thrown at a certain initial height will travel the farthest distance when the initial angle is $30^{\circ}$, and will travel the shortest distance when the angle is $60^{\circ}$. The development of the MATLAB code in this modeling aims to provide a qualitative description as a supporter of a quantitative understanding of parabolic motion, where so far textbooks only emphasize the quantitative aspect.
\end{abstract}

Kata kunci: Parabolic motion, Modelling, GUI Matlab 


\section{Pendahuluan}

Dalam kajian ilmu fisika terdapat banyak persamaan matematis dan konsep-konsep bersifat abstrak yang sulit dipersepsikan secara indra oleh peserta didik. Kemampuan memahami fisika berbeda-beda sesuai dengan tingkat intuisi masing-masing peserta didik [1]. Peserta didik yang memiliki intuisi yang bagus, cenderung dapat dengan mudah memahami konsep fisika dan dapat menyelesaikan soal fisika dengan cepat. Intuisi dapat dilatih dan ditingkatkan dengan memberikan visualisasi baik dalam bentuk visualisasi diam seperti gambar, grafik, dan foto maupun dalam bentuk visualisasi bergerak seperti video, pemodelan, simulasi, dan animasi [2],[3],[4],[5]. Visualisasi dapat mengatasi abstraksi persoalan fisika, meningkatkan pemahaman konsep fisika peserta didik pada sekolah menengah dan mahasiswa sains teknik [6],[7]. Mahasiswa menunjukkan peningkatan pemahaman pada topik tertentu ketika diberikan visualisasi dan simulasi dari pada hanya menyajikan persamaan matematis dan penjelasan verbal. Menurut [8], visualisasi menggunakan gambar bergerak lebif efektif dibandingkan menggunakan gambar diam.

Visualisasi konsep fisika dalam bentuk visualisasi bergerak seperti animasi maupun pemodelan telah dilakukan beberapa peneliti, antara lain melakukan simulasi gerak vertikal kebawah menggunakan Visual Basic for Application (VBA) di Microsoft Excel [9]. Simulasi menggunakan Microsfot Excel cukup menarik namun fitur-fitur animasi yang disediakan masih sangat terbatas. Alternatif lain yaitu menggunakan program Adobe Flash. Program Adobe Flash cukup populer digunakan dalam pembuatan animasi konsep fisika pada level perguruan tinggi seperti mata kuliah fisika dasar dan fisika modern [10],[11]. Meskipun program ini memiliki tampilan animasi yang menarik dan kaya akan fitur, pembuatan animasi melalui Abode Flash cukup rumit sehingga penyelesaiannya membutuhkan waktu yang relatif lama. Untuk mengatasi permasalahan tersebut dapat menggunakan visualisasi dan animasi dengan bantuan Graphical User Interaction (GUI) pada aplikasi MATLAB. Matlab (Matrix Laboratory) merupakan aplikasi interaktif untuk komputasi numerik dan visualisasi data, memiliki fasilitas pengembangan berupa GUI. GUI mengandung menu, tombol, grafik dan pengguna (user) dapat mengubahnya secara interaktif [12]. GUI pada MATLAB memiliki banyak fitur untuk membuat animasi dengan pemrograman yang relatif lebih mudah.

Salah satu topik yang dipelajari dalam fisika dasar adalah kinematika gerak parabola. Pada umumnya, pengguna membuat simulasi gerak parabola dengan asumsi ketinggian awal $h=0$ yang berarti benda dilemparkan dari permukaan tanah [13],[14]. Pada penelitian ini, akan dilakukan variasi ketinggian awal pelemparan benda untuk melihat respon waktu tempuh, waktu maksimum, jarak tempuh, jangkauan maksimum dan ketinggian maksimum. Selain itu akan dilakukan variasi nilai parameter sudut dan kecepatan awal. Pada pemodelan ini diasumsikan gaya gesek udara diabaikan. Pengembangan kode matlab pada pemodelan ini bertujuan untuk memberikan gambaran kualitatif sebagai pendukung pemahaman secara kuantitatif gerak parabola, dimana selama ini buku teks hanya menekankan pada aspek kuantitatifnya. Kinematika gerak parabola dijelaskan secara rinci dari aspek kuantitatif, namun dalam hal gambaran kualitatif baru sebatas pada visualisasi gambar diam berupa grafik [15]. Hal yang sama ditemukan pada buku-buku teks lain pada umumnya, sehingga sangat diperlukan gambaran dari aspek visualisasi bergerak berbasis GUI Matlab. 


\section{Metode}

Penelitian ini terdiri dari 4 (empat) tahapan besar yaitu analisis persamaan gerak parabola, pembuatan GUI, implementasi persamaan gerak ke dalam program MATLAB, ujicoba dan evaluasi. Tahapan-tahapan tersebut dilakukan secara berurutan sampai program dapat berfungsi dengan baik. Detail setiap tahapan dijelaskan sebagai berikut:

\subsection{Analisis persamaan gerak parabola}

Ilustrasi lintasan gerak parabolah objek yang dilempar dari ketinggian awal tertentu dapat dilihat pada Gambar 1.

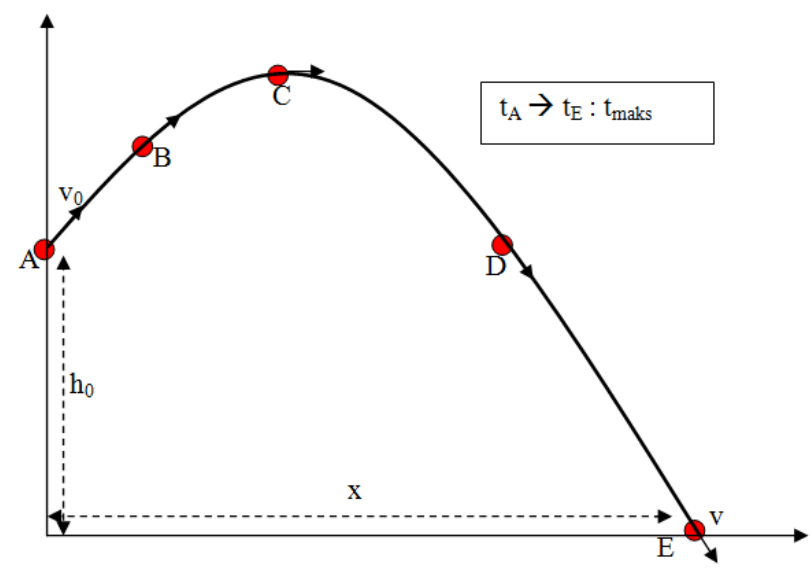

Gambar 1. Lintasan gerak parabola objek dari ketinggian awal tertentu

Persamaan matematis yang menjadi dasar pada pemodelan gerak parabola

$$
\begin{aligned}
& x=v_{0} t \cos \theta \\
& h=h_{0}+v_{0} t \sin \theta-\frac{1}{2} g t^{2} \\
& v_{x}=v_{0} \cos \theta \\
& v_{y}=v_{0} \sin \theta-g t
\end{aligned}
$$

Ketika benda dilemparkan dari ketinggian tertentu, lama benda benda tersebut berada di udara ( $\left.t_{\text {maks }}\right)$ dapat ditentukan dari persamaan (2) dengan syarat $h=0$, sehingga

$$
\begin{aligned}
& 0=h_{0}+v_{0} t \sin \theta-\frac{1}{2} g t^{2} \\
& \frac{1}{2} g t^{2}-v_{0} \cdot \sin \theta \cdot t-h_{0}=0
\end{aligned}
$$

Nilai $t$ dapat diperoleh dengan mencari akar-akar persamaan (5)

$$
t_{1,2}=\frac{-b \pm \sqrt{b^{2}-4 a c}}{2 a}
$$

dimana:

$a=1 / 2 g \quad b=-v_{0} \sin \theta \quad c=-h_{0}$

Simbol dan keterangan pada persamaan $1-4$ di atas dijelaskan pada Tabel 1. 
Tabel 1. Nama besaran dan satuan pada persamaan gerak parabola

\begin{tabular}{cll}
\hline Simbol & \multicolumn{1}{c}{ Nama besaran } & \multicolumn{1}{c}{ Satuan } \\
\hline$x$ & jarak jangkauan mendatar objek & meter $(\mathrm{m})$ \\
$h$ & $\begin{array}{l}\text { ketinggian objek dari permukaan } \\
\text { tanah }\end{array}$ & meter $(\mathrm{m})$ \\
$t$ & waktu tempuh & sekon $(\mathrm{s})$ \\
$v_{0}$ & kecepatan awal & meter per sekon $(\mathrm{m} / \mathrm{s})$ \\
$h_{0}$ & ketinggian awal & meter $(\mathrm{m})$ \\
$v_{x}$ & kecepatan mendatar & meter per sekon $(\mathrm{m} / \mathrm{s})$ \\
$v_{y}$ & kecepatan vertikal & meter per sekon $(\mathrm{m} / \mathrm{s})$ \\
$\theta$ & sudut awal & derajat \\
$t_{\text {maks }}$ & lama objek di udara & sekon $(\mathrm{s})$ \\
$g$ & percepatan gravitasi bumi & meter per sekon \\
& & kuadrat $\left(\mathrm{m} / \mathrm{s}^{2}\right)$ \\
\hline
\end{tabular}

\subsection{Pembuatan GUI}

Pemodelan dilakukan menggunakan program MATLAB R2015b di PC 64-bit dengan OS Windows 7. GUI merupakan tampilan interaktif antara user dan sistem. GUI dilengkapi dengan menu input, menu output, tombol proses, tombol reset, dan tampilan grafik bergerak. Menu input adalah tempat untuk memasukkan nilai parameter kecepatan awal, ketinggian awal, dan sudut pelemparan dan nilai tersebut dapat divariasikan sesuai kebutuhan pengguna. Menu output menampilkan nilai parameter keluaran antara lain ketinggian akhir, jangkauan objek, waktu tempuh, dan kecepatan objek. Tombol proses berguna untuk menjalankan program, sedangkan tombol reset untuk mengatur ulang nilai parameter input. Tampilan GUI dapat dilihat pada Gambar 2.

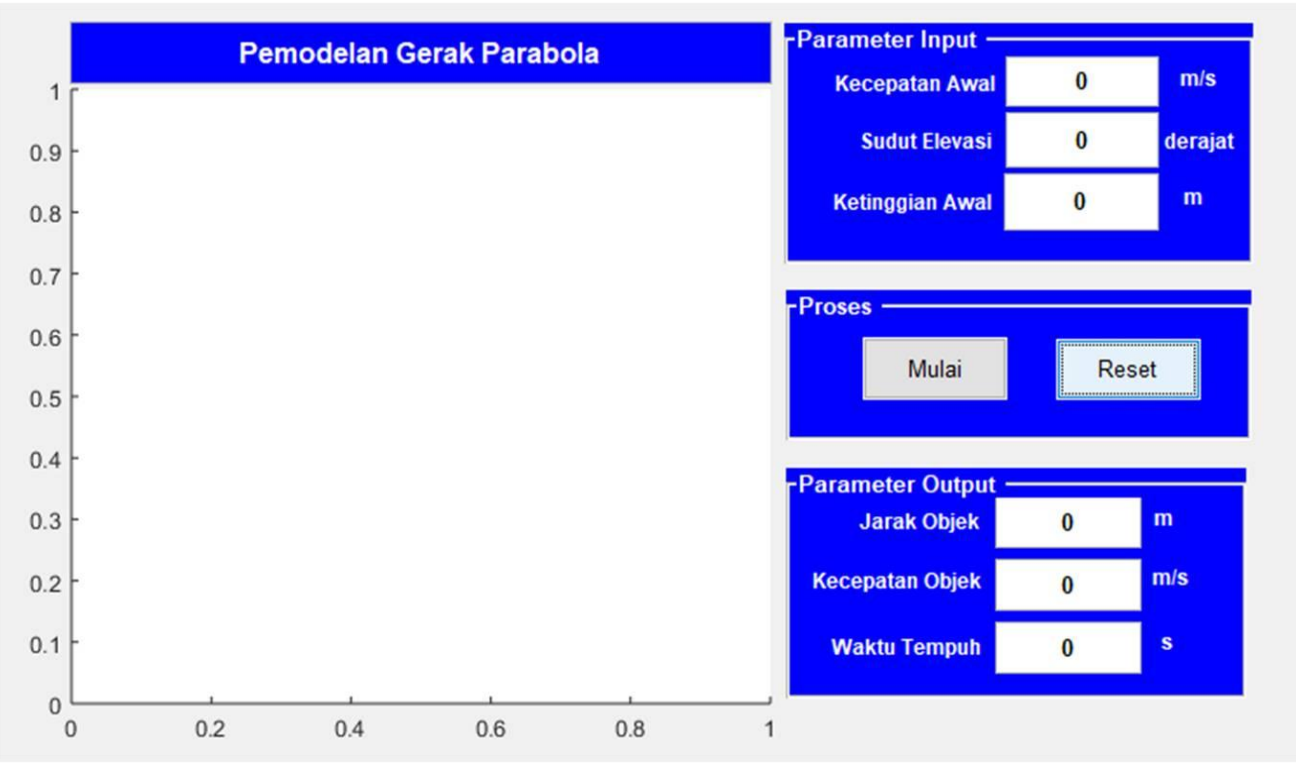

Gambar 2. Tampilan GUI pemodelan gerak parabola 


\subsection{Impelementasi persamaan gerak ke dalam GUI MATLAB}

Persamaan gerak yang telah dijabarkan kemudian diimplemantasikan ke dalam GUI Matlab yang telah dibuat sesuai dengan algoritma seperti disajikan pada Gambar 3.
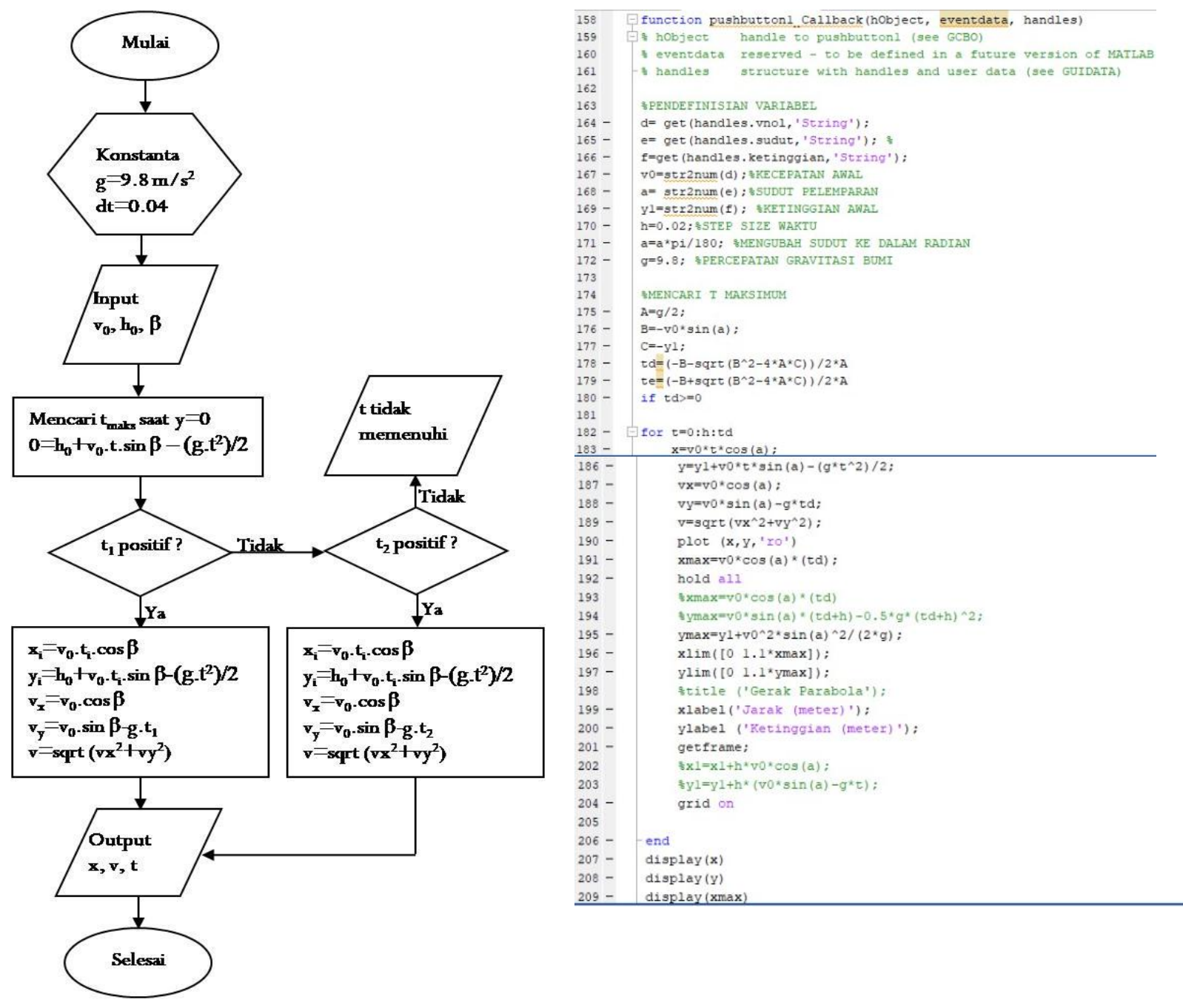

Gambar 3. Flowchart dan kode matlab pemodelan gerak parabola

\subsection{Ujicoba dan Evaluasi}

Tahap pengujian dilakukan dengan memvariasikan nilai ketinggian awal, sudut pelemparan, dan kecepatan awal objek serta melihat pola lintasan yang dihasilkan. Pada tahap ini juga dilihat apakah semua fitur pada GUI matlab yang telah dibuat dapat berfungsi dengan baik dan menampilkan output yang diinginkan

\section{Hasil dan Pembahasan}

Pemodelan berbasis GUI Matlab menampilkan visual yang menarik dan dapat menggambarkan gerak parabola secara kualitatif dan kuantitatif. Fitur-fitur dapat dengan mudah ditambahkan dan diubah sesuai keinginan pengguna. Grafik yang dihasilkan berupa grafik bergerak yaitu menampilkan gerakan objek mulai dari dilemparkan sampai jatuh ke tanah. Sebagai contoh pada Gambar 1, nilai 
ketinggian awal divariasikan dengan menjaga nilai sudut awal dan kecepatan awal konstan. Sudut awal dibuat konstan pada sudut $30^{\circ}$ dan kecepatan awal sebesar $20 \mathrm{~m} / \mathrm{s}$. Nilai ketinggian awal yang digunakan yaitu $10 \mathrm{~m}, 20 \mathrm{~m}, 30 \mathrm{~m}, 40 \mathrm{~m}$, dan $50 \mathrm{~m}$. Variasi ketinggian awal ini dapat diatur pada perangkat pemodelan yang dirancang seperti tampak pada Gambar 4.

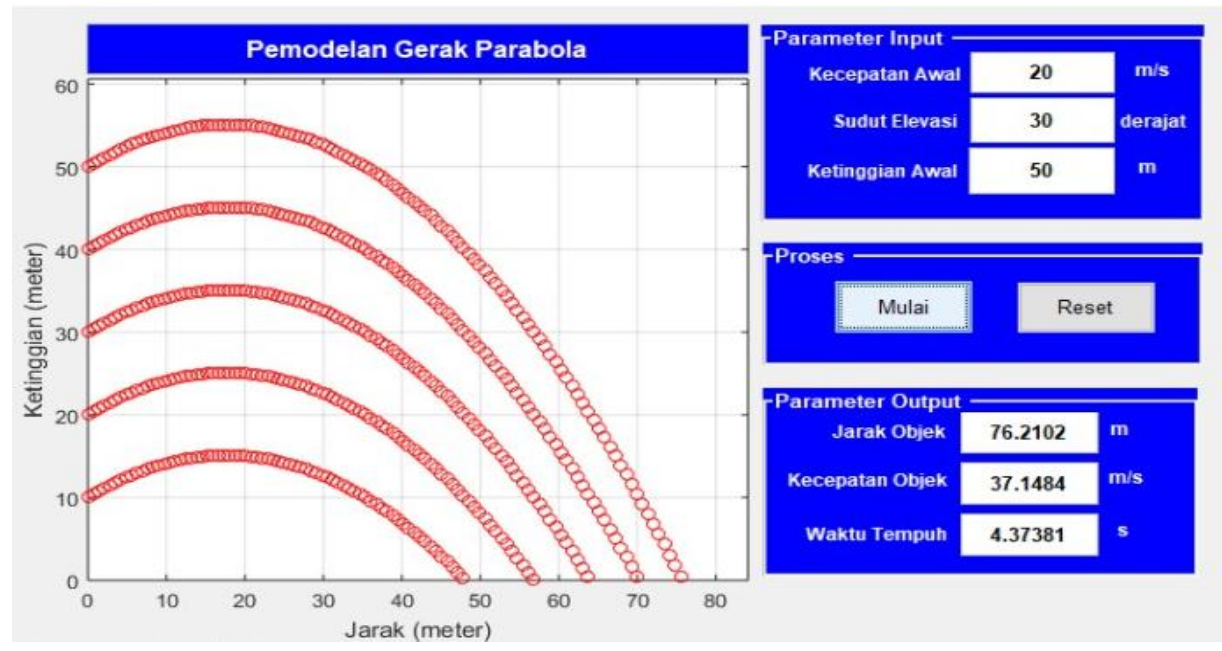

Gambar 4. Variasi nilai ketinggian awal

Dari Gambar 4 dapat dilihat objek yang dilempar dengan ketinggian awal yang semakin besar membuat jauh jangkauan objek tersebut semakin jauh. Kecepatan akhir dan waktu tempuh objek semakin besar seiring dengan pertambahan nilai ketinggian awal pelemparan objek tersebut. Nilai jarak, kecepatan, dan waktu tempuh untuk masing-masing ketinggian awal dapat dilihat pada Tabel 2.

Tabel 2. Perubahan jarak, kecepatan, dan waktu tempuh terhadap ketinggian awal

\begin{tabular}{cl}
\hline Ketinggian awal (m) & \multicolumn{1}{c}{ Output } \\
& $x=48.4974 \mathrm{~m}$ \\
10 & $v=24.4131 \mathrm{~m} / \mathrm{s}$ \\
$t$ & $=2.77 \mathrm{~s}$ \\
& $x=57.504 \mathrm{~m}$ \\
& $v=28.1425 \mathrm{~m} / \mathrm{s}$ \\
& $t=3.28 \mathrm{~s}$ \\
\hline 20 & $x=64.4323 \mathrm{~m}$ \\
& $v=31.4325 \mathrm{~m} / \mathrm{s}$ \\
$t=3.69 \mathrm{~s}$ \\
\hline 30 & $x=70.6677 \mathrm{~m}$ \\
& $v=34.4093 \mathrm{~m} / \mathrm{s}$ \\
& $t=4.05 \mathrm{~s}$ \\
& $x=76.2102 \mathrm{~m}$ \\
& $v=37.1484 \mathrm{~m} / \mathrm{s}$ \\
& $t=4.37 \mathrm{~s}$ \\
\hline
\end{tabular}


Parameter berikutnya yang divariasikan adalah nilai kecepatan awal, yaitu $10 \mathrm{~m} / \mathrm{s}, 15 \mathrm{~m} / \mathrm{s}, 20 \mathrm{~m} / \mathrm{s}$, $25 \mathrm{~m} / \mathrm{s}$, dan $30 \mathrm{~m} / \mathrm{s}$ dengan membuat nilai sudut awal dan ketinggian awal konstan secara berturutturut sebesar $30^{\circ}$ dan $50 \mathrm{~m}$. Hasil pemodelan dengan variasi kecepatan awal dapat dilihat pada gambar 5. Dari gambar 5 dapat dilihat bawah perubahan nilai kecepatan awal objek sangat mempengaruhi jarak jangkauan objek tersebut. Semakin besar nilai kecepatan awal akan membuat jangkauan objek semakin jauh. Nilai kecepatan dan waktu tempuh juga mengalami peningkatan akan tetapi tidak terlalu signifikan, hasil tersebut dapat ditunjukkan pada Gambar 5.

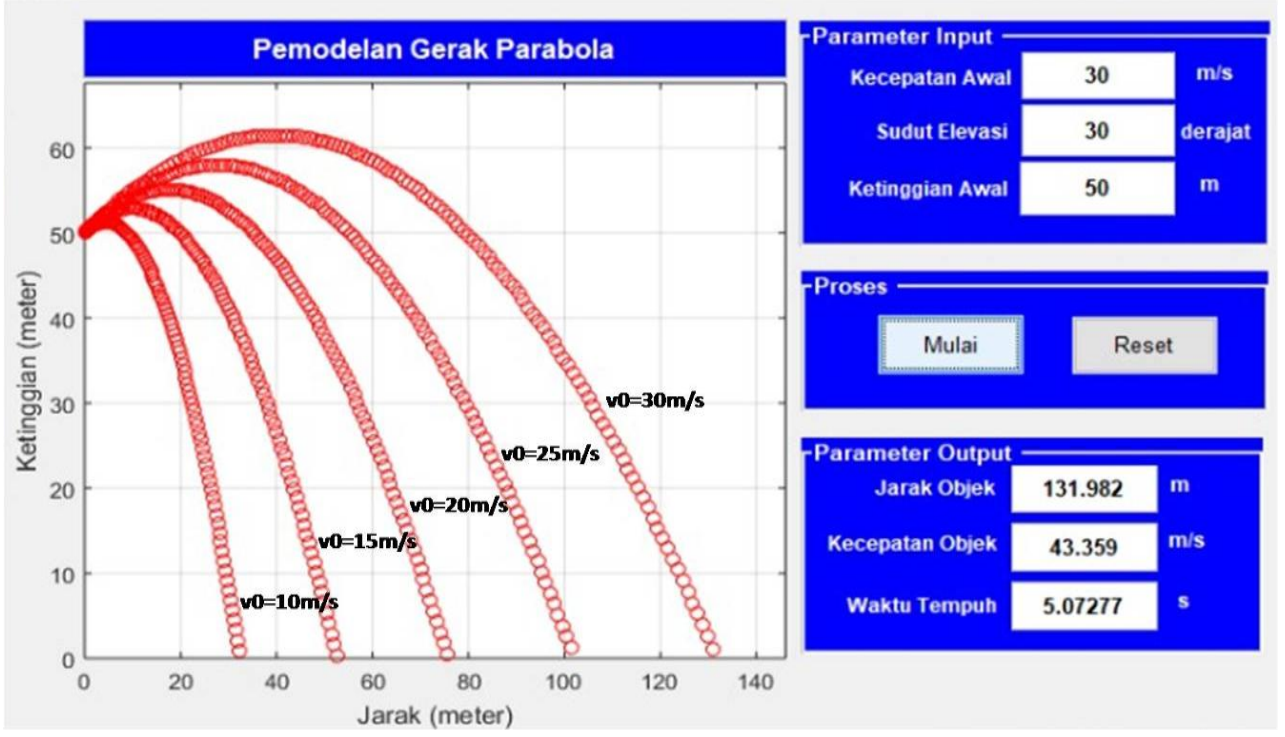

Gambar 5. Variasi nilai kecepatan awal

Parameter selanjutnya yang divariasikan adalah sudut pelemparan, yaitu sebesar $0^{\circ}, 15^{\circ}, 30^{\circ}, 45^{\circ}$, dan $60^{\circ}$ dengan membuat konstan nilai kecepatan awal sebesar $20 \mathrm{~m} / \mathrm{s}$ dan ketingggian awal sebesar $50 \mathrm{~m}$. Hasil pemodelan dengan variasi sudut pelemparan dapat dilihat pada Gambar 6 .

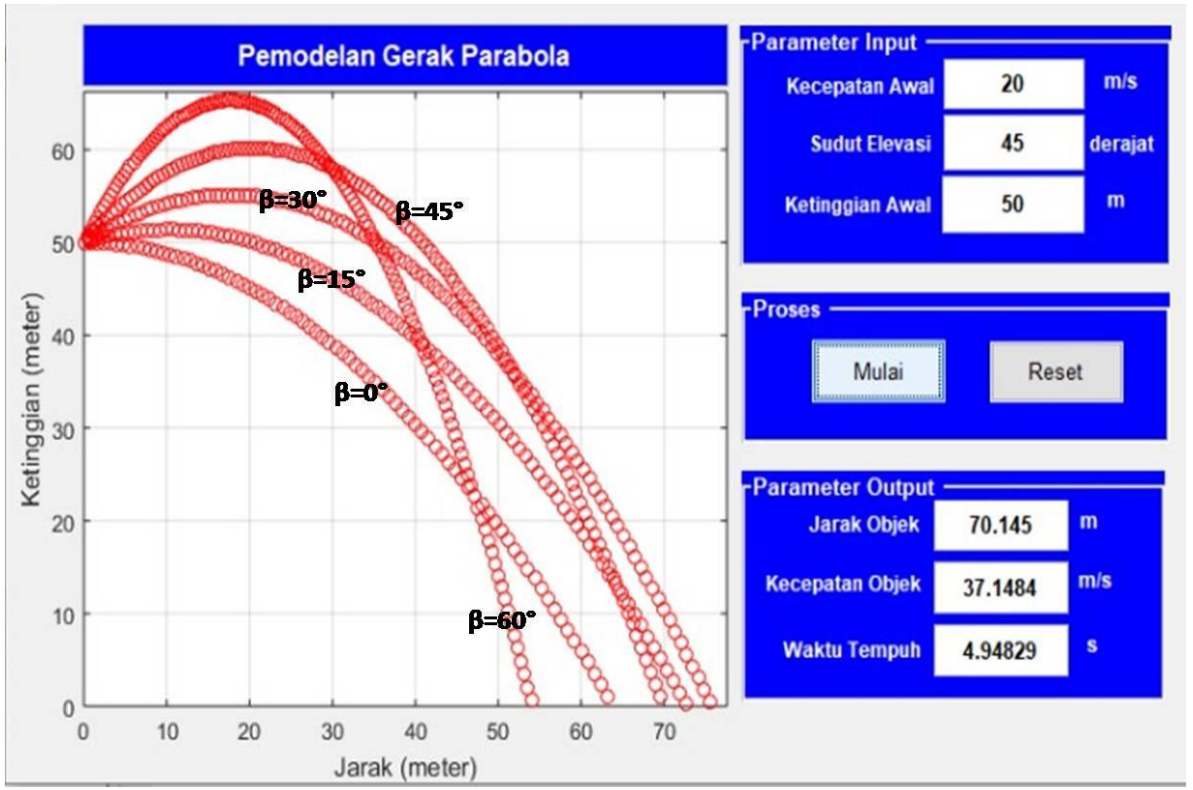

Gambar 6. Variasi sudut pelemparan 
Terdapat hal menarik pada variasi sudut ini, dimana jarak terjauh terjadi pada saat sudut pelemparan $30^{\circ}$. Hal berbeda terjadi apabila pelemparan dilakukan dari atas tanah $\left(h_{0}=0\right)$, dimana sudah umum diketahui bahwa jarak terjauh terjadi saat sudut pelemparan sebesar $45^{\circ}$ [15],[16],[17]. Selain itu, justru jarak terpendek ditempuh bukan pada saat sudut pelemparan $0^{\circ}$, akan tetapi pada saat sudut pelemparan $60^{\circ}$. Menarik untuk disimulasikan lebih lanjut untuk sudut pelemparan diatas sudut $60^{\circ}$, bagaimana pola lintasan yang akan terbentuk. Pada penelitian ini, masih berupa studi awal sehingga belum dilakukan eksperimen secara langsung sebagai validasi dari pemodelan ini sehingga menarik untuk dikaji lebih lanjut.

\section{Kesimpulan}

Pemodelan gerak parabola berbasis GUI Matlab pada penelitian ini menampilkan visualisasi bergerak berupa gerakan objek dari posisi pelemparan dengan ketinggian awal tertentu dari permukaan tanah sampai objek menyentuh tanah. Pemodelan ini dapat menampilkan hasil secara kualitatif dan secara kuantitatif, serta mudah untuk mengubah fitur pada GUI sesuai keinginan pengguna. Dari hasil pemodelan, objek yang dilempar pada ketinggian awal tertentu akan menempuh jarak terjauhnya saat sudut pelemparan awal sebesar $30^{\circ}$, dan akan menempuh jarak terpendeknya saat sudut pelemparan sebesar $60^{\circ}$. Saran dari penelitian ini adalah perlu dilakukan perbandingan dengan uji lapangan secara eksperimen untuk melihat kesesuaian hasil pemodelan dengan hasil eksperimen.

\section{Daftar Pustaka}

[1] A. Suyatna, D. Anggraini, D. Agustina, and D. Widyastuti, "The role of visual representation in physics learning: dynamic versus static visualization," in Journal of Physics: Conference Series, 2017, vol. 909, no. 1, p. 12048.

[2] S. Apipah, Kartono, and Isnarto, "An analysis of mathematical connection ability based on student learning style on visualization auditory kinesthetic (VAK) learning model with self-assessment," J. Phys. Conf. Ser., vol. 983, no. 1, 2018, doi: 10.1088/1742-6596/983/1/012138.

[3] M. Liyanage, S. Piyatissa, and A. K. Tarofder, "Impact of Visualization on Teaching and Learning Physics At Secondary School Level,” Eur. J. Educ. Stud., vol. 0, no. 0, pp. 114-144, 2018, doi: 10.5281/zenodo. 1241479 .

[4] B. C. Sanders, T. Senden, and V. Springel, "Focus on visualization in physics," New J. Phys., vol. 10, no. 12, p. 125001, 2008.

[5] J. L. Anderson and S. D. Wall, "Kinecting Physics: Conceptualization of Motion Through Visualization and Embodiment," J. Sci. Educ. Technol., vol. 25, no. 2, pp. 161-173, 2016, doi: 10.1007/s10956-015-9582-4.

[6] L. Milana and E. D. Jannati, "Inovasi Model Pembelajaran Problem Based Learning Dengan Visualisasi Virtual Untuk Meningkatkan Pemahaman Konsep Pada Matakuliah Fisika Dasar I," WaPFi (Wahana Pendidik. Fis., vol. 3, no. 1, p. 19, 2018, doi: 10.17509/wapfi.v3i1.10933.

[7] Y. Yunita, A. Halim, and R. Safitri, "Meningkatkan Penguasaan Konsep Mahasiswa Dengan Simulasi Physics Eduaction and Technology (PhET)," J. Pendidik. Sains Indones. (Indonesian J. Sci. Educ., vol. 7, no. 1, pp. 16-22, 2019. 
[8] D. Agustina, A. Suyatna, and E. Suyanto, "Gambar bergerak atau animasi menurut Ali (2011) adalah 'Termasuk ke dalam Media motion-visual, yakni media yang mempunyai gambar obyek bergerak, tapi tanpa mengeluarkan suara, seperti film bisu yang bergerak'.," J. Pembelajaran Fis., vol. 5, no. 1, pp. 25-34, 2017.

[9] E. Randjawali, R. Dany, and J. R. S. No, "PROSIDING SKF 2016 Simulasi Benda yang Dilepas Horizontal dan Benda yang Dijatuhkan Vertikal Menggunakan VBA pada Microsoft Excel," no. September, pp. 122-125, 2016.

[10] A. M. Yusuf, "Pengembangan Media Pembelajaran Berbasis Adobe Flash untuk Mata Kuliah Fisika Modern Materi Radiasi Benda Hitam,” J. Sains Dan Pendidik. Fis., vol. 11, no. 1, 2015.

[11] B. Syefrinando, S. Suraida, and A. Parman, "Pengembangan Media Pembelajaran Fisika berbasis Adobe Flash Professional CS6 Untuk Mata Kuliah Fisika Dasar I," J. Endidikan Fis. dan Teknol., vol. 6, no. 1, pp. 39-44, 2020.

[12] Yulia Fitri, Delovita Ginting, Shabri Putra Wirman, Neneng Fitrya, Sri Fitria Retnawaty, and Noni Febriani, "Pelatihan Penggunaan Aplikasi Gui Matlab Untuk Materi Dinamika Gerak," J. Pengabdi. UntukMu NegeRI, vol. 4, no. 2, pp. 206-210, 2020, doi: 10.37859/jpumri.v4i2.2116.

[13] C. Rajagukguk, J; Sarumaha, "Pemodelan dan analisis gerak parabola dua dimensi dengan menggunakan aplikasi GUI matlab,” J. Ikat. Alumni Fis. Univ. Negeri Medan, vol. 4, no. 4, pp. 1$5,2018$.

[14] K. Yetilmezsoy and C. E. Mungan, "MATLAB time-based simulations of projectile motion, pendulum oscillation, and water discharge," Eur. J. Phys., vol. 39, no. 6, p. 65803, 2018.

[15] M. Abdullah, "Fisika Dasar I," Bandung, Inst. Teknol. Bandung, 2016.

[16] J. Walker et al., "Halliday \& Resnick Fundamentals of Physics (Extended 10th Edition)," 2013.

[17] D. C. Giancoli, Physics: principles with applications, vol. 4. Pearson/Prentice Hall Upper Saddle River, NJ, 2005. 